\title{
SMOKING IN PREGNANCY, MATERNAL BLOOD PRESSURE, PREGNANCY OUTCOME, BABY WEIGHT AND GROWTH, AND OTHER RELATED FACTORS
}

\author{
A PROSPECTIVE STUDY \\ BY \\ C. SCOTT RUSSELL, M.A., M.D., F.R.C.S., F.R.C.O.G., \\ Professor, Department of Obstetrics and Gynaecology, University of Sheffield, \\ R. TAYLOR, S.R.N., S.C.M., M.T.D., \\ Departmental Research Sister, Department of Obstetrics and Gynaecology, University of Sheffield, \\ AND \\ C. E. LAW, \\ Research Assistant, Computing Laboratory, University of Sheffield
}

In an interesting paper Campbell (1936), while welcoming the studies that were being concentrated on improving maternity care, drew attention to what he called "a more subtle and sinister condition", the "excessive smoking" which, during the previous two decades, had "clutched the young women of this country (America) in a manner resembling the invasion of an epidemic working in virgin soil".

His paper, which was based on the conviction of his own observations, included his review of the literature and in particular a review of such experimental work as there was on the effect of nicotine or tobacco extracts. Campbell had also asked the members of the American Association of Obstetricians and Gynaecologists for their opinion about the effect of smoking 25 cigarettes or more daily on maternal health and he quoted some of the interesting replies he received, the great majority of which supported his beliefs that excessive smoking in pregnancy was harmful to the mother. There was no suggestion in his paper that smoking might also have an effect on the foetus.

Since then smoking in pregnancy has received spasmodic attention. A few workers have presented evidence to suggest that smoking may prevent a successful outcome to the pregnancy (Frazier, Davis, Goldstein, and Goldberg, 1961; Zabriskie, 1963; Butler, 1965; Russell, Taylor, and Maddison, 1966; Steele and Langworth, 1966), but most have not been able to show any such effect. Simpson (1957) reported a higher incidence of premature births (by weight) among smokers and since then an increasing number of workers have been able to show that when smokers and non-smokers are compared the smokers have the smaller babies (Lowe, 1959; Herriot, Billewicz, and Hytten, 1962; Savel and Roth, 1962;
Järvinen and Österlund, 1963; Murdoch, 1963; O'Lane, 1963; Zabriskie, 1963; Baird, 1964; Yerushalmy, 1964; Butler, 1965; MacMahon, Alpert, and Salber, 1965; Ounsted, 1965; Peterson, Morese, and Kaltreider, 1965; Ravenholt and Levinski, 1965; Tanaka, 1965; Underwood, Hester, Laffitte, and Gregg, 1965; Abernathy, Greenberg, Wells, and Frazier, 1966; Downing and Chapman, 1966; Reinke and Henderson, 1966; Russell and others, 1966; Underwood, Kesler, O'Lane, and Callagan, 1967). There have also been many recent review articles also drawing attention to this difference (Goldberg, Foster, Segerson, and Baumeister, 1963; Apgar, 1964; Goldstein, Goldberg, Frazier, and Davis, 1964; Hirokawa, 1964; Kistner, 1964; Rosenbaum, 1964; Dawkins, 1965; Howren, 1965; Jonge, 1965; Jansson, 1966; Steele and Langworth, 1966). Questions of course remain. Does being smaller carry any disadvantage, and if it does is it due to a direct effect of the smoking or some associated factor?

Though there can no longer be room for any reasonable doubt that when smokers and nonsmokers are compared the former have smaller babies, opinions differ as to the meaning of these differences. The majority of workers subscribe to the view that the smaller babies born to smokers are smaller because of some direct effect of the smoking. The arguments in favour include: nicotine given to the experimental animal lowers the foetal weight (Mosier and Armstrong, 1964), or even leads to foetal malformation or loss if the amount given is greater (Robson, 1963; Gatling, 1964; Pitel and Lerman, 1964); women working with tobacco products are particularly liable to abortion and stillbirth (Simpson, 1957); and smoking raises the content of carboxy 
haemoglobin in both maternal and foetal blood (Haddon, Nesbitt, and Garcia, 1961; Heron, 1962; Young and Pugh, 1963; Mantell, 1964; Tanaka, 1965). Despite the smaller babies, many workers have been unable to demonstrate any mortality as a result of maternal smoking. The explanation may sometimes be quite simple. Certain papers have been based on retrospective studies of delivered women and such studies, besides carrying the drawback of all retrospective studies, are open to the criticism that, starting as they often do from delivered women in maternity hospitals or from notified births, they may never have a chance of including women who have aborted.

Yerushalmy (1964) in particular has maintained that the smaller size of the foetus is not a consequence of the smoking per se but is rather due to some associated factor. His paper is difficult to interpret for he writes about neonatal mortality and does not mention either stillbirths or abortions; also his study though prospective was restricted to "only pregnancies which terminated in single live birth". Therefore cases resulting in stillbirth or abortion have been excluded, and these are clearly an important part of any study about the influence of maternal factors on pregnancy outcome. Our experience (Russell and others, 1966) has been that if stillbirths, neonatal deaths, and abortions are taken together it is possible to show an overall significant difference in pregnancy outcome between the smokers and the non-smokers.

In the present paper foetal size and growth has been related to the maternal smoking pattern and to various associated matters in an attempt to establish what factors are chiefly responsible for the smaller size of the babies born to smokers.

\section{Material ANd Methods}

The prospective survey of which this paper is a part was started a number of years ago with the object of relating with greater accuracy the events in pregnancy with its outcome and with the development of the child.

Women attending the two main maternity units in Sheffield were chosen and certain selected facts about them were recorded by Senior Research Midwives employed whole-time on the project. The accuracy of each case record was confirmed at weekly meetings with the two medical members of the research team (Prof. C. S. Russell and Dr. Pamela Wray). The women chosen comprised a reasonably representative sample of those attending the two main maternity units in Sheffield; thus a fair number of young primigravidae booking early were chosen, together with women threatening to abort, some with a bad obstetric history and others with medical, surgical, and $\mathscr{C}$ obstetrical disorders. The information about each patient was recorded on a special form, the contents of which were transferred to punched paper tape and checked at several levels. The babies were examined by the paediatricians and the details about the baby in the first year of life were likewise punched on paper tape. At the close of the data-collecting part of the study, which was spread over some 4 to 5 years, the paediatric data were matched and joined to the corresponding obstetric data. Analysis has been by computer.

\section{Maternal SMOKING}

Among other matters the mothers were classified according to their smoking habit into five groups: Group 1-non-smokers; Group 2-occasional smokers; Group 3-regular smokers of about five cigarettes a day; Group 4-regular smokers of about ten a day; and Group 5-smokers of twenty cigarettes or more a day. In this paper the five groups have been reduced to two: non-smokers and occasional smokers taken together (for convenience called non-smokers) and regular smokers. This simplified grouping is the same as that used by Goldstein and others (1964).

\section{Maternal Blood Pressure}

When this investigation was at the planning stagê, very much time and thought was given to the possible ways of grouping the mothers according to their overall blood pressure. There was a limit to what could be done with the staff available, and it was therefore decided to make the grouping as practical as possible.

The border-land between a normal and an abnormal blood pressure in obstetrics has been for many years a pressure of $140 / 90$ and at the outset it was thought that at least there must be the two groups of women: those whose blood pressure was occasionally $140 / 90$ and those whose blood pressure was usually in this region. It was also thought wise to classify those showing a blood pressure below $140 / 90$ into two groups: just below $140 / 90$, say $130 / 80$, and even lower, 120/70. These groupings were fairly clean-cut and seldom caused any difficulty. Several different levels of blood pressure above $140 / 90$ were originally recorded, but the numbers were too small for separate analysis and all levels above the group usually $140 / 90$ have been taken together. The placing of each patient in the appropriate group was a team decision taken after delivery. It is appreciated that this grouping of patients can be criticized as too subjective, but against this it may be said that it probably reflects 
reasonably clearly the kind of assessment that any group of obstetricians and senior midwives in the U.K. would make, and that it was practicable and realistic in terms of everyday obstetric practice. The grouping was made independently of any other factors. It has been further simplified in this paper by placing the mothers into three well-defined classes: below $140 / 90$, occasionally or usually at a level of $140 / 90$, and at or above $150 / 100$. The last group will have included those with severe pre-eclamptic toxaemia. Other groupings are self-explanatory.

\section{RESULTS}

\section{Blood Pressure and Maternal Smoking}

When maternal blood pressure and smoking were compared, highly significant $(\mathrm{P}<0.001)$ differences were seen (Table I). The lowest blood pressure group contained relatively more smokers and the highest blood pressure group relatively less. The interpretation of this difference is difficult. Two possibilities come to mind - that low blood pressures in some way encourage smoking, and high pressure discouraged it; and that maternal smoking actually lowered the pressure. Whatever the explanation, the difference deserves closer examination because if it is a real difference it could be a serious source of confusion to those trying to interpret the significance of blood pressure readings in obstetrical practice.

TABLE I

MATERNAL SMOKING AND BLOOD PRESSURE LEVELS

\begin{tabular}{c|c|c}
\hline \multicolumn{1}{c|}{ Blood Pressure } & Total Mothers & Percentage Smokers \\
\hline$<140 / 90$ & 1,480 & $33 \cdot 5$ \\
Occasionally or usually 140/90 & 457 & $25 \cdot 6$ \\
$\geqslant 150 / 100$ & 173 & $20 \cdot 2$ \\
\hline
\end{tabular}

The association of a lower blood pressure with more smoking, and of a higher blood pressure with less smoking at once raised the possibility that the smoking might even be helpful. That this is not so is shown by the percentage unsuccessful (abortion, stillbirth, and neonatal death taken together) outcome of the pregnancy (Table II).

TABLE II

BLOOD PRESSURE LEVELS AND PERCENTAGE UNSUCCESSFUL PREGNANCY (ABORTION OR STILLBIRTH OR NEONATAL DEATH) FOR NON-SMOKERS AND SMOKERS

\begin{tabular}{l|cl|rr}
\hline \multirow{2}{*}{ Blood Pressure } & \multicolumn{2}{|c|}{ Unsuccessful Pregnancy (per cent.) } \\
\cline { 2 - 4 } & \multicolumn{2}{|c|}{ Non-smokers } & \multicolumn{2}{|c}{ Smokers } \\
\hline $\begin{array}{l}<140 / 90 \\
\text { Occasionally or usually } \\
140 / 90\end{array}$ & $2 \cdot 7$ & $(984)$ & $6 \cdot 5$ & $(496)$ \\
$\geqslant 150 / 100$ & $4 \cdot 1$ & $(340)$ & $6 \cdot 8$ & $(117)$ \\
\hline
\end{tabular}

Numbers of mothers are shown in parentheses.
The overall unsuccessful outcome rate among smokers ( 7.9 per cent.) is higher than that for nonsmokers ( $4 \cdot 1$ per cent.), the difference being highly significant $(P<0.001)$. At every level of blood pressure the smokers have performed less well; but attention is particularly drawn to the unsuccessful pregnancy rate of 31 per cent. among smokers with a blood pressure at or above 150/100 compared with an unsuccessful pregnancy rate of 14.5 per cent. for non-smokers in the same blood pressure group. Clearly those who smoke with a high blood pressure, have the worst results and those who do not smoke with a low blood pressure have the best.

Table III, which relates smoking to foetal weight, also shows three differences to which attention is drawn:

(i) At each blood pressure level the smokers clearly had smaller babies;

(ii) (and this is no more than a confirmatory hint that blood pressure levels and smoking are related) The overall trend of smaller babies and higher pressure is just reversed for the smokers in the two lower pressure groups;

(iii) The babies born to mothers with pressures at $150 / 100$ or higher were clearly smaller than the others.

TABLE III

FOETAL WEIGHTS (OZ.) FOR NON-SMOKERS AND SMOKERS BY MATERNAL BLOOD PRESSURE LEVELS Means and standard errors

\begin{tabular}{l|c|c}
\hline \multirow{2}{*}{\multicolumn{1}{c|}{ Blood Pressure }} & \multicolumn{2}{|c}{ Foetal Weight (oz.) } \\
\cline { 2 - 3 } & Non-smokers & Smokers \\
\hline $\begin{array}{l}\text { Occasionally or usually } \\
140 / 90\end{array}$ & $117 \cdot 2 \pm 0 \cdot 7$ & $107 \cdot 2 \pm 1 \cdot 0$ \\
$\geqslant 150 / 100$ & $114 \cdot 2 \pm 1 \cdot 2$ & $108 \cdot 9 \pm 2 \cdot 4$ \\
$99 \cdot 3 \pm 2 \cdot 6$ & $90 \cdot 8 \pm 5 \cdot 8$ \\
\hline
\end{tabular}

Because of this third feature, the highest pressure group has been omitted for all subsequent comparisons in this paper unless otherwise stated. The records of multiple pregnancies have also been omitted.

Maternal Smoking and Certain Other Factors

With the exclusions just mentioned various associated factors were examined in relation to maternal smoking. The factors chosen were, consort's social class, maternal age, pregnancy number, father's social class, maternal height, maternal educational level as judged by the possession of a General Certificate of Education or not, consort's age, mother's attitude to her pregnancy, and work in the three pregnancy trimesters. 
Table IV, which shows these associated factors and their subgroups, gives numbers of cases and percentages of smokers. Simple inspection of the column percentage smokers shows that, apart from work in pregnancy, there are differences in the direction of more smoking as the associated factor gets less favourable. Excepting the differences for maternal height $(P>0 \cdot 1)$ and for maternal attitude to pregnancy $(P>0.05)$, these differences are all highly significant. At first sight it follows therefore that any reduction in the size of the baby that might be attributed to smoking could be wholly or in part an effect of one or more associated factors with which smoking was linked. This is not the case as can be shown.

\section{TABLE IV}

FACTORS OTHER THAN SMOKING ASSOCIATED WITH BIRTH WEIGHT

\begin{tabular}{|c|c|c|c|c|}
\hline \multicolumn{3}{|c|}{ Possible Associated Factors } & $\begin{array}{l}\text { No. of } \\
\text { Mothers }\end{array}$ & $\begin{array}{l}\text { Percentage } \\
\text { Smokers }\end{array}$ \\
\hline \multicolumn{2}{|c|}{ Consort's Social Class } & $\begin{array}{l}1 / 2 \\
3 \\
4 / 5\end{array}$ & $\begin{array}{r}243 \\
1,235 \\
512\end{array}$ & $\begin{array}{l}21 \cdot 8 \\
31 \cdot 5 \\
36 \cdot 9\end{array}$ \\
\hline \multicolumn{2}{|c|}{ Maternal Age (yrs) } & $\begin{array}{l}15- \\
25- \\
35-\end{array}$ & $\begin{array}{l}671 \\
967 \\
368\end{array}$ & $\begin{array}{l}29 \cdot 2 \\
30 \cdot 2 \\
40 \cdot 8\end{array}$ \\
\hline \multicolumn{2}{|l|}{ Parity } & $\begin{array}{l}1 \\
2 / 3 / 4 \\
\geqq 5\end{array}$ & $\begin{array}{l}675 \\
974 \\
354\end{array}$ & $\begin{array}{l}25 \cdot 5 \\
32 \cdot 5 \\
42 \cdot 1\end{array}$ \\
\hline \multicolumn{2}{|c|}{ Father's Social Class } & $\begin{array}{l}1 / 2 \\
3 \\
4 / 5\end{array}$ & $\begin{array}{l}159 \\
928 \\
675\end{array}$ & $\begin{array}{l}23 \cdot 3 \\
29 \cdot 1 \\
34 \cdot 1\end{array}$ \\
\hline \multicolumn{2}{|c|}{ Maternal Height } & $\begin{array}{l}\geq 5^{\prime} 5^{\prime \prime} \\
5^{\prime} 1^{\prime \prime}-5^{\prime} 4^{\prime \prime} \\
\text { Under } 5^{\prime} 1^{\prime \prime}\end{array}$ & $\begin{array}{r}402 \\
1,124 \\
327\end{array}$ & $\begin{array}{l}28 \cdot 6 \\
31 \cdot 9 \\
33 \cdot 3\end{array}$ \\
\hline \multicolumn{2}{|c|}{ Possession of G.C.E. } & $\begin{array}{l}\text { Yes } \\
\text { No }\end{array}$ & $\begin{array}{r}237 \\
1,769\end{array}$ & $\begin{array}{l}19 \cdot 4 \\
33 \cdot 5\end{array}$ \\
\hline \multicolumn{2}{|c|}{ Consort's Age (yrs) } & $\begin{array}{l}15- \\
25- \\
35-\end{array}$ & $\begin{array}{r}366 \\
1,054 \\
577\end{array}$ & $\begin{array}{l}29 \cdot 8 \\
28 \cdot 7 \\
39 \cdot 0\end{array}$ \\
\hline \multicolumn{2}{|c|}{$\begin{array}{l}\text { Maternal Attitude to } \\
\text { Pregnancy }\end{array}$} & $\begin{array}{l}\text { Wanted } \\
\text { Doubtful } \\
\text { Not wanted }\end{array}$ & $\begin{array}{r}1,342 \\
397 \\
247\end{array}$ & $\begin{array}{l}30 \cdot 3 \\
34 \cdot 3 \\
36 \cdot 8\end{array}$ \\
\hline \multirow{3}{*}{ Work } & Ist Trimester & $\begin{array}{l}\text { None } \\
\text { Part-time } \\
\text { Full-time }\end{array}$ & $\begin{array}{r}1,098 \\
162 \\
741\end{array}$ & $\begin{array}{l}32 \cdot 8 \\
30 \cdot 2 \\
30 \cdot 5\end{array}$ \\
\hline & 2nd Trimester & $\begin{array}{l}\text { None } \\
\text { Part-time } \\
\text { Full-time }\end{array}$ & $\begin{array}{r}1,302 \\
96 \\
525\end{array}$ & $\begin{array}{l}33 \cdot 2 \\
31 \cdot 3 \\
29 \cdot 9\end{array}$ \\
\hline & 3rd Trimester & $\begin{array}{l}\text { None } \\
\text { Part-time } \\
\text { Full-time }\end{array}$ & $\begin{array}{r}1,559 \\
28 \\
94\end{array}$ & $\begin{array}{c}31 \cdot 7 \\
\text { Numbers } \\
\text { too small } \\
29 \cdot 8\end{array}$ \\
\hline
\end{tabular}

Mean Foetal Weight and Maternal Smoking

In Table $\mathrm{V}$ (opposite) mean foetal weights and their standard errors for smokers and non-smokers are compared for these different factors. The following observations may be made:

(1) In each of the 32 comparisons the smokers have the smaller babies.

(2) Three factors (maternal age, parity, and the age of consort), though significantly associated with smoking (Table IV), were not obviously related to foetal weight. Clearly therefore these factors could not be responsible for the smoking effect which can be seen in all nine subgroups.

(3) Three other factors (consort's social class, father's social class, and maternal educational level) besides being significantly associated with smoking were also related to foetal weight. These factors could therefore have been responsible for the smoking effect: but this is not so because, in the eight comparisons in the subgroups of these factors, the smoking effect is clearly distinguishable as a separate effect.

(4) Of the remaining factors (below the dotted line), none of which were significantly related to smoking, only one (maternal height) was related to foetal size.

\section{INFLUENCE OF SEX OF Foetus}

Though it seems rather pointless to spend too much time looking at the sex of the foetus in relation to maternal smoking, foetal mean weights for all cases excluding multiple births have been calculated for foetal sex, maternal smoking, and duration of pregnancy (Table VI, opposite). The marginal totals and the figures within the Table show that the smokers always had smaller babies for all durations of pregnancy. As expected, the mean foetal weights rose with advancing pregnancy duration. With regard to foetal sex, in every comparison bar one females were the smaller. Though the overall differences in mean weights of male and female is highly significant $(\mathrm{P}<0.001)$, it is rather less than the overall difference between the foetal weights of smokers and non-smokers. Clearly both factors are related to foetal size, but smoking appears to be marginally the more important of the two.

\section{INTERIM CONCLUSION}

At this stage the following conclusion seems to be justified. Maternal smoking is certainly associated with lower foetal weight and this association is clearly and unequivocally independent of maternal age, parity, height, educational level, attitude to pregnancy or work in pregnancy, father's social class, consort's social class, and sex of the child or premature delivery. 
TABLE V

MEAN FOETAL WEIGHTS (OZ.) AND THEIR STANDARD ERRORS

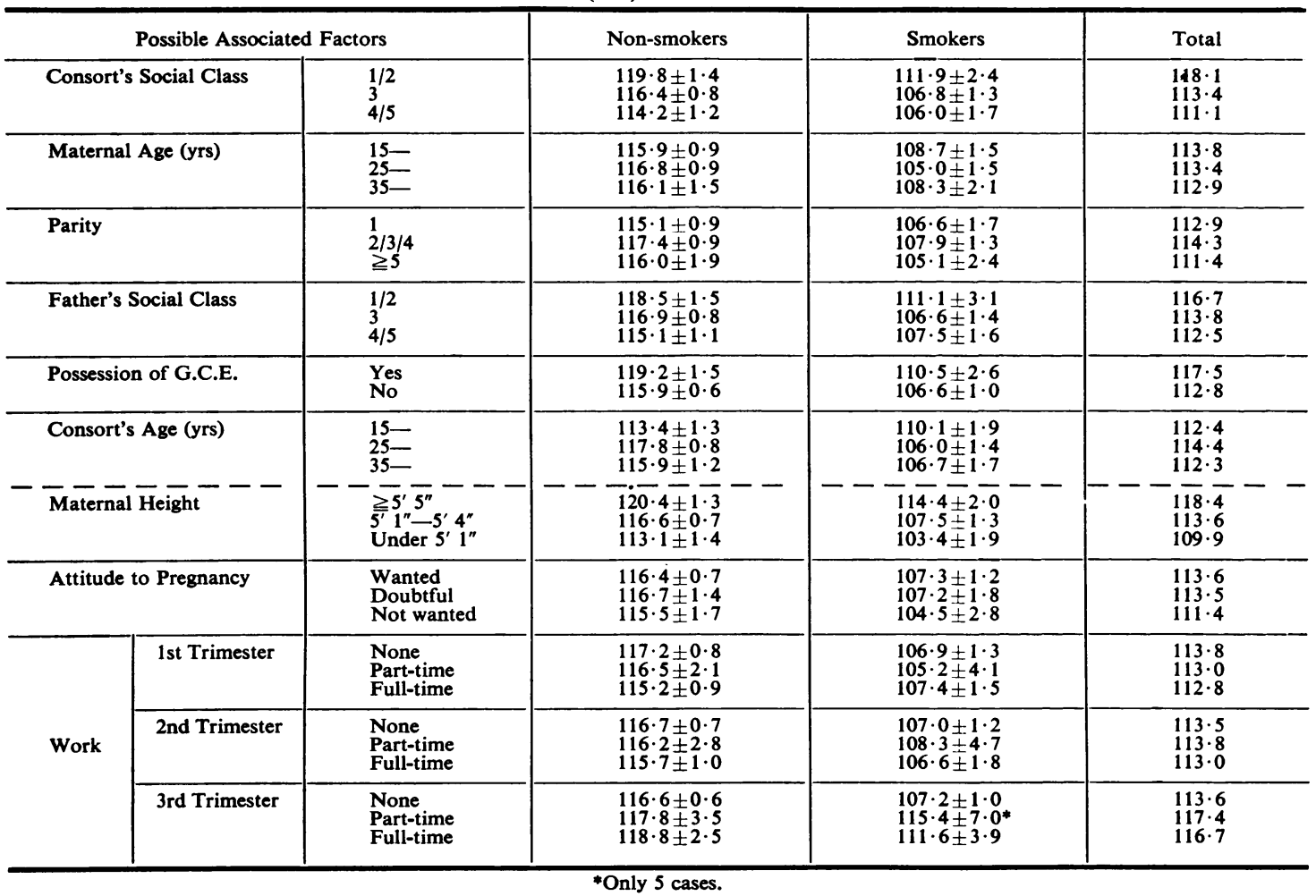

TABLE VI

FOETAL WEIGHTS (OZ.) FOR SMOKERS AND NON-SMOKERS BY DURATION OF PREGNANCY (WKS) AND SEX OF CHILD Means and standard errors

\begin{tabular}{|c|c|c|c|c|c|c|c|}
\hline \multirow{2}{*}{ Sex of Child } & \multirow{2}{*}{ Mother's Smoking } & \multicolumn{6}{|c|}{ Duration of Pregnancy (wks) } \\
\hline & & $28-$ & 36 & $38-$ & $40-$ & $42-$ & Total \\
\hline \multirow[t]{2}{*}{ Male } & $\begin{array}{l}\text { Non-smoker } \\
\text { Smoker }\end{array}$ & $\begin{array}{c}68 \cdot 0 \pm 4 \cdot 8 \\
(27) \\
62 \cdot 3 \pm 3 \cdot 1 \\
(25)\end{array}$ & $\begin{array}{c}97 \cdot 7 \pm 2 \cdot 7 \\
(69) \\
91 \cdot 1 \pm 3 \cdot 1 \\
(39)\end{array}$ & $\begin{array}{c}113 \cdot 7 \pm 1 \cdot 4 \\
(192) \\
108 \cdot 5 \pm 2 \cdot 0 \\
(80)\end{array}$ & $\begin{array}{c}125 \cdot 5 \pm 0.9 \\
(377) \\
117 \cdot 9 \pm 1 \cdot 4 \\
(148)\end{array}$ & $\begin{array}{c}125 \cdot 8 \pm 2 \cdot 0 \\
(70) \\
123 \cdot 1 \pm 2 \cdot 9 \\
(32)\end{array}$ & $\begin{array}{c}117 \cdot 7 \pm 0 \cdot 8 \\
(735) \\
108 \cdot 6 \pm 1 \cdot 3 \\
(324)\end{array}$ \\
\hline & Total & $65 \cdot 3 \pm 2 \cdot 9$ & $\begin{array}{c}95 \cdot 3 \pm 2 \cdot 1 \\
(108)\end{array}$ & $\begin{array}{l}112 \cdot 2 \pm 1 \cdot 2 \\
(272)\end{array}$ & $\begin{array}{c}123 \cdot 4 \pm 0 \cdot 8 \\
(525)\end{array}$ & $\begin{array}{c}124 \cdot 9 \pm 1 \cdot 7 \\
(102)\end{array}$ & $\begin{array}{c}114 \cdot 9 \pm 0 \cdot 7 \\
(1,059)\end{array}$ \\
\hline \multirow[t]{2}{*}{ Female } & $\begin{array}{l}\text { Non-smoker } \\
\text { Smoker }\end{array}$ & $\begin{array}{c}61 \cdot 4 \pm 3 \cdot 6 \\
(32) \\
59 \cdot 5 \pm 4 \cdot 4 \\
(27)\end{array}$ & $\begin{array}{c}97 \cdot 9 \pm 2 \cdot 9 \\
(61) \\
92 \cdot 0 \pm 3 \cdot 4 \\
(35)\end{array}$ & $\begin{array}{c}111 \cdot 0 \pm 1 \cdot 3 \\
(191) \\
103 \cdot 6 \pm 1 \cdot 8 \\
(90)\end{array}$ & $\begin{array}{c}118 \cdot 5 \pm 0 \cdot 9 \\
(337) \\
114 \cdot 4 \pm 1 \cdot 5 \\
(129)\end{array}$ & $\begin{array}{c}122 \cdot 5 \pm 1 \cdot 7 \\
(70) \\
120 \cdot 0 \pm 3 \cdot 0 \\
(34)\end{array}$ & $\begin{array}{c}112 \cdot 3 \pm 0 \cdot 8 \\
(691) \\
104 \cdot 7 \pm 1 \cdot 4 \\
(315)\end{array}$ \\
\hline & Total & $\begin{array}{c}60 \cdot 6 \pm 2 \cdot 8 \\
(59)\end{array}$ & $\begin{array}{c}95 \cdot 8 \pm 2 \cdot 2 \\
(96)\end{array}$ & $\begin{array}{c}108 \cdot 6 \pm 1 \cdot 1 \\
(281)\end{array}$ & $\begin{array}{c}117 \cdot 3 \pm 0 \cdot 8 \\
(466)\end{array}$ & $\begin{array}{c}121 \cdot 7 \pm 1 \cdot 5 \\
(104)\end{array}$ & $\begin{array}{c}110 \cdot 0 \pm 0 \cdot 7 \\
(1,006)\end{array}$ \\
\hline
\end{tabular}

Numbers of mothers in parentheses.

Smoking, Apgar Score, and Sex of Child

It has already been shown (Russell and others, 1966) that maternal smoking is significantly associated with unsuccessful pregnancy, and it was therefore thought wise to examine the average Apgar score for smokers and non-smokers by sex of child. Both the male babies and those born to the smokers had the lower scores, but the differences are only marginal (Table VII, overleaf).

Can the Surviving Children Born to Smokers AND NON-SMOKeRS BE DisTINGUISHED?

If maternal smoking acts by slightly poisoning the foetus (as seems likely), it is possible that after birth 
TABLE VII

MEAN APGAR SCORES AND THEIR STANDARD ERRORS FOR MATERNAL SMOKING AND SEX OF CHILD Means and standard errors

\begin{tabular}{|c|c|c|c|}
\hline \multirow{2}{*}{ Mother's Smoking } & \multicolumn{3}{|c|}{ Sex of Child } \\
\hline & Male & Female & Total \\
\hline $\begin{array}{l}\text { Non-smoker } \\
\text { Smoker }\end{array}$ & $\begin{array}{c}8 \cdot 3: 0 \cdot 1 \\
(710) \\
8 \cdot 2: 0 \cdot 1 \\
(316)\end{array}$ & $\begin{array}{c}8 \cdot 4: 0 \cdot 1 \\
(677) \\
8 \cdot 4: 0 \cdot 1 \\
(299)\end{array}$ & $\begin{array}{c}8 \cdot 3: 0 \cdot 1 \\
(1,387) \\
8 \cdot 3: 0 \cdot 1 \\
(615)\end{array}$ \\
\hline Total & $\begin{array}{c}8 \cdot 2: 0 \cdot 1 \\
(1,026\end{array}$ & $\begin{array}{l}8 \cdot 4 \div 0 \cdot 1 \\
\quad(976)\end{array}$ & $\begin{array}{c}8 \cdot 3+0 \cdot 1 \\
(2,002)\end{array}$ \\
\hline
\end{tabular}

Numbers of mothers in parentheses.

the babies so poisoned might grow more quickly. This hypothesis was tested by comparing the weight gain in ounces per week and the head circumference gain in $\mathrm{mm}$. per week for surviving babies born to smokers and non-smokers from birth to the second, third, and fourth examination of the child (Table VIII). The differences at the second examination made about the 6th week of life and at the third examination made about the 6th month are significant $(P<0.05)$, but the later differences are not. The more rapid growth of the babies born to the smokers seems to have worn off by the fourth examination held at about one year.

In order to present a more complete picture of the growth pattern, another set of calculations have been made; the weight of the child was divided by the estimated conception age, and means computed
(Table IX). These means therefore refer to the average weekly increase in weight since conception*. These foetal weight gains of smokers and non-smokers are significantly different $(\mathrm{P}<0.001)$ at birth and at the second examination of the child, but not thereafter. However, it may be worth noting that even at one year the smokers' babies have grown less though the difference is not significant. Assuming this final examination took place 50 weeks after birth and the duration of pregnancy was 40 weeks, then the difference recorded amounts to $4 \frac{1}{2}$ ounces. We have not followed up the babies after one year so that any later differences are as yet unknown.

For completeness, a similar calculation was made for babies born to mothers showing a blood pressure at or below $140 / 90$ and at or over $150 / 100$, and a somewhat similar picture emerged (Table $\mathrm{X}$, opposite).

As in the smoking comparison, the means are significantly different at birth $(\mathrm{P}<0.001)$ and at the second examination of the child $(\mathrm{P}<0 \cdot 05)$, but not thereafter.

\section{SUMmary}

A review of the literature including our own previous work has brought to light irrefutable

* This is not strictly true as the calculation has been based on th last menstrual period, but care was taken at the time this survey wa being carried out to make reasonably certain that the recorded first day of the LMP preceded ovulation by only 2 weeks.

TABLE VIII

WEIGHT GAIN (OZ.) AND HEAD CIRCUMFERENCE GAIN (MM.) PER WEEK FROM BIRTH TO SECOND, THIRD, AND FOURTH EXAMINATION OF THE CHILD, FOR SMOKERS AND NON-SMOKERS Means and standard errors

\begin{tabular}{|c|c|c|c|c|c|}
\hline Gain per Week & Mother's Smoking & $\begin{array}{l}\text { Birth to 2nd Examination } \\
\text { (6th week) }\end{array}$ & $\begin{array}{c}\text { Birth to 3rd Examination } \\
\text { (6th month) }\end{array}$ & $\begin{array}{r}\text { Birth to } 4 \text { th Ex } \\
\text { (1st yea }\end{array}$ & ar) \\
\hline \multirow[t]{2}{*}{ Weight (oz.) } & $\begin{array}{l}\text { Smoker } \\
\text { Non-smoker }\end{array}$ & $\begin{array}{lr}7 \cdot 29 \pm 0 \cdot 10 \\
7 \cdot 03 \pm 0.06\end{array}$ & $\begin{array}{l}6.48 \pm 0.06 \quad(419) \\
6.32 \pm 0.04 \quad(1,100)\end{array}$ & $\begin{array}{l}4 \cdot 75 \pm 0 \cdot 04 \\
4 \cdot 72 \pm 0 \cdot 03\end{array}$ & $\begin{array}{r}(416) \\
(1,105)\end{array}$ \\
\hline & Difference & $0 \cdot 26$ & $0 \cdot 16$ & \multicolumn{2}{|l|}{0.03} \\
\hline \multirow{2}{*}{$\begin{array}{l}\text { Head } \\
\text { Circumference } \\
\text { (mm.) }\end{array}$} & $\begin{array}{l}\text { Smoker } \\
\text { Non-smoker }\end{array}$ & $\begin{array}{rr}5 \cdot 54 \pm 0.08 \\
5 \cdot 32 \pm 0.05 \quad(1,159)\end{array}$ & $\begin{array}{l}3.42 \pm 0.03 \quad(389) \\
3.35 \pm 0.02 \quad(1,052)\end{array}$ & $\begin{array}{l}2 \cdot 42 \pm 0 \cdot 02 \\
2 \cdot 38 \pm 0 \cdot 01\end{array}$ & $\begin{array}{r}(388) \\
(1,059)\end{array}$ \\
\hline & Difference & $0 \cdot 22$ & 0.07 & \multicolumn{2}{|l|}{0.04} \\
\hline
\end{tabular}

Numbers of babies in parentheses.

TABLE IX

WEIGHT OF CHILD (OZ). DIVIDED BY THE ESTIMATED CONCEPTION AGE PLUS 2 WEEKS FOR SMOKERS AND NON-SMOKERS (MULTIPLE BIRTHS EXCLUDED) Means and standard errors

\begin{tabular}{|c|c|c|c|c|c|}
\hline \multicolumn{2}{|c|}{ Mother's Smoking } & \multirow{2}{*}{$\frac{\text { Non-smoker }}{2 \cdot 91 \pm 0 \cdot 013(1,404)}$} & \multicolumn{2}{|c|}{ Smoker } & Total \\
\hline \multirow{4}{*}{$\begin{array}{l}\text { Weight gain } \\
\text { (oz.) per week } \\
\text { of conception } \\
\text { age }\end{array}$} & At birth & & $2 \cdot 73 \pm 0 \cdot 020$ & (619) & $2 \cdot 86 \pm 0 \cdot 011(2,023)$ \\
\hline & At second examination (6th week) & $3 \cdot 52 \pm 0 \cdot 014(1,214)$ & $3 \cdot 43 \pm 0 \cdot 023$ & (489) & $3 \cdot 50 \pm 0 \cdot 012(1,703)$ \\
\hline & At third examination (6th month) & $4 \cdot 30 \pm 0 \cdot 017(1,100)$ & $4 \cdot 27 \pm 0 \cdot 028$ & (419) & $4 \cdot 29 \pm 0 \cdot 014(1,519)$ \\
\hline & At fourth examination (1st year) & $3 \cdot 91 \pm 0 \cdot 015(1,105)$ & $3 \cdot 87 \pm 0 \cdot 025$ & $(416)$ & $3.90 \pm 0.013(1,521)$ \\
\hline
\end{tabular}


TABLE X

WEIGHT OF CHILD (OZ.) DIVIDED BY ESTIMATED CONCEPTION AGE PLUS 2 WEEKS AGAINST BLOOD PRESSURE (MULTIPLE BIRTHS EXCLUDED) Means and standard errors

\begin{tabular}{|c|c|c|c|c|}
\hline \multicolumn{2}{|c|}{ Mother's Blood Pressure } & $140 / 90$ or Less & At or over $150 / 100$ & Total \\
\hline \multirow{4}{*}{$\begin{array}{l}\text { Weight gain } \\
\text { (oz.) per week } \\
\text { of conception } \\
\text { age }\end{array}$} & At birth & $2 \cdot 88 \pm 0 \cdot 011(1,883)$ & $2 \cdot 67 \pm 0.052$ & $2 \cdot 87 \pm 0.011(2,033)$ \\
\hline & At second examination (6th week) & $3 \cdot 51 \pm 0 \cdot 012(1,584)$ & $3.41 \pm 0.050$ & $3 \cdot 50 \pm 0.012(1,710)$ \\
\hline & At third examination (6th month) & $4 \cdot 30 \pm 0 \cdot 015(1,420)$ & $4 \cdot 26 \pm 0.057 \quad(109)$ & $4 \cdot 29 \pm 0.014(1,529)$ \\
\hline & At fourth examination (1st year) & $3 \cdot 90 \pm 0.014(1,420)$ & $3.92 \pm 0.045$ & $3.90 \pm 0.013(1,534)$ \\
\hline
\end{tabular}

evidence that mothers who smoke regularly have smaller babies than those who do not smoke. Though there is much evidence that the fact that the babies are smaller is likely to be a direct consequence of the smoking, there are still those who do not accept this view, maintaining that any effect is probably due to associated factors. Certainly very little practical advice is being offered to pregnant women in regard to smoking.

A prospective study of over 2,000 pregnant women has been analysed in order to determine what relationship there is between the smoking habit, the pregnancy outcome, and the weight and subsequent development of the child. In particular, maternal smoking has been compared with factors that might be linked to smoking and might themselves be responsible for any effect that would otherwise be attributable to the smoking. The main yardstick for these comparisons has been the mean birth weight.

In the first instance, maternal blood pressure, which had been grouped into three broad categories (i.e. below, occasionally or usually $140 / 90$, or at or above 150/100) was compared with maternal smoking and an interesting relationship was found. The lowest pressure levels were associated with an unusually high proportion of smokers and the highest levels with a low proportion of smokers. Explanations for this and its possible importance have been discussed. When pregnancy outcome was related to blood pressure levels and maternal smoking, a significant difference was found implicating smoking as an additional hazard. Especially was this apparent for blood pressure levels at or above $150 / 100$. The mean foetal weights for the highest blood pressure group was much lower than for the other two groups, and for this reason this group was excluded (as were twins and triplets) from all subsequent comparisons in which the mean birth weights were used as the measure of possible harmful effects.

The frequency of maternal smoking was compared with a number of factors, which might themselves be responsible for smaller foetal weight. These factors were: social class of consort, maternal age, parity, maternal height, social class of woman's father, educational level, age of consort, maternal attitude to the pregnancy, work in pregnancy, and sex of offspring. As expected, a number of these factors were linked with maternal smoking and might therefore have been responsible for the smaller babies. When, however, mean foetal weights were compared for smoking and each of the other factors in turn, it was quite clear that the smoking effect, which was obvious in every comparison made, was clearly independent of each of the other factors, whether or not the factor was linked with smoking, and whether or not it was itself linked to smaller babies.

The results therefore lend no support whatever to any suggestion that the smaller babies born to smokers are smaller because of associated factors. Smoking per se is implicated without any reasonable shadow of doubt.

The mean Apgar score for smokers and nonsmokers and for male and female offspring showed only marginal differences.

If smoking acts as a slight poison retarding foetal growth, it might be expected that after birth the smaller babies of smokers would grow more quickly. This hypothesis has been supported by the finding of a significantly increased weight gain and head circumference gain per week in the early weeks of life in the babies of the regular smokers compared with the others.

The mean weight gain per week in terms of estimated conception age (duration of pregnancy plus age after birth) has been compared for regular smokers and non-smokers. Until about the 6th month of life significant differences were found, confirming smoking as a growth retarder, but there were subsequently no significant differences $(P<0.05)$ though at the age of about one year the babies of mothers smoking regularly were still smaller than those born to non-smoking mothers.

A somewhat similar pattern to that of smoking was found for the surviving babies born to mothers with a blood pressure at or above $150 / 100$. 
We wish to thank those members of the original research team who are no longer in Sheffield, $\mathrm{Mr}$ Blundell, Miss Serviss, Miss Michelson, Dr Pamela Wray; Professor Illingworth and Dr Gordon who with their staff examined the babies; and Dr Richard N. Maddison wno completed the variate structure programme and put it into operation. We thank Dr Harley of the National Lending Library of Science and Technology for his help with the Medlars Search of the literature, and others in Sheffield and elsewhere who helped with the translations.

Finally we acknowledge the considerable financial support from the National Spastics Society and the Medical Research Council

\section{REFERENCES}

Abernathy, J. R., Greenberg, B. G., Wells, H. B., and Frazier, T. M. (1966). Amer. J. Publ. Hlth, 56, 626 (Smoking as an independent variable in a multiple regression analysis upon birth weight and gestation).

Apgar, V. (1964). J. Amer. med. Ass., 190, 840 (Drugs in pregnancy).

Baird, D. (1964). J. Pediat., 65, 909 (The epidemiology of prematurity).

Butler, N. R. (1965). J. Obstet. Gynaec. Brit. Cwlth, 72, 1001 (The problems of low birthweight and early delivery).

Campbell, A. M. (1936). Amer. J. Obstet. Gynec., 31, 502 (The effect of excessive cigaret smoking on maternal health)

Dawkins, M. (1965). Develop. Med. Child Neurol., 7, 74 (The biology of prematurity).

Downing, G. C., and Chapman, W. E. (1966). Calif. Med., 104, 187 (Smoking and pregnancy: a statistical study of 5,659 patients).

Frazier, T. M., Davis, G. H., Goldstein, H., and Goldberg, I. D. (1961). Amer. J. Obstet. Gynec., 81, 988 (Cigarette smoking and prematurity: a prospective study).

Gatling, R. R. (1964). Arch. Path. (Chicago), 78, 652 (Effect of nicotine on chick embryo).

Goldberg, B., Foster, D. B., Segerson, J. A., and Baumeister, J. (1963). Bull. Menninger Clin., 27, 275 (Congenital brain malformations in the mentally retarded).

Goldstein, H., Goldberg, I. D., Frazier, T. M., and Davis, G. E. (1964). Publ. Hlth Rep. (Wash.), 79, 553 (Cigarette smoking and prematurity).

Haddon, W., Nesbitt, R. E. L., and Garcia, R. (1961). Obstet. Gynec., 18, 262 (Smoking and pregnancy: carbon monoxide in blood during gestation and at term).

Heron, H. J. (1962). N.Z. med. J., 61, 545 (The effects of smoking during pregnancy: a review with a preview).

Herriot, A., Billewicz, W. Z., and Hytten, F. E. (1962). Lancet, 1, 771 (Cigarette smoking in pregnancy).

Hirokawa, O. (1964). J. Jap. med. Ass., 52, 133 (On the problems of causes of premature births). [In Japanese.]

Howren, H. H., Jr., (1965). Virginia Med. Mthly., 92, 274 (A review of the literature concerning smoking during pregnancy).

Jansson, I. (1966). Acta obstet. gynaec. scand. 45, 279 (Aetiological factors in prematurity).

Järvinen, P. A., and Österlund, K. (1963). Ann. paediat. Fenn., 9, 18 (Effect of smoking during pregnancy on the fetus, placenta and delivery).
Jonge, G. A. de (1965). Folia med. neerl., 8, 65 (Fetal $\varnothing$ damage caused by pharmaceutical agents). [Dutch.]

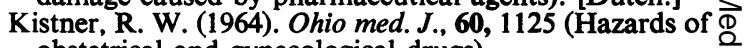
obstetrical and gynecological drugs).

Lowe, C. R. (1959). Brit. med. J. 2, 673 (Effect of mothers' smoking habits on birth weight of their $\stackrel{\oplus}{+}$ children).

MacMahon, B., Alpert, M., and Salber, E. J. (1965). Amer. J. Epidem., 82, 247 (Infant weight and parental $\overline{\bar{\omega}}$ smoking habits).

Mantell, C. D. (1964). N.Z. med. J., 63, 601 (Smoking $\stackrel{\Phi^{\circ}}{2}$ in pregnancy: the role played by carbonic anhydrase). مు

Mosier, H. D., and Armstrong, M. K. (1964). Proc. Soc. Exp. Biol. (N.Y.), 116, 956 (Effects of maternal intake $\vec{O}$ of nicotine on fetal and newborn rats).

Murdoch, D. E. (1963). Nebraska med. J., 48, 604 (Birth $\vec{\omega}$ weight and smoking).

O'Lane, J. M. (1963). Obstet. and Gynec., 22, 181 (Some $\overparen{D}$ fetal effects of maternal cigaret smoking).

Ounsted, M. (1965). Develop. Med. Child Neurol., 7, $479 \stackrel{\text { N }}{\supset}$ (Maternal constraint of foetal growth in man).

Peterson, W. F., Morese, K. N., and Kaltreider, D. F. $\omega$ (1965). Obstet. and Gynec., 26, 775 (Smoking and prematurity: a preliminary report based on study of $\vec{v}$ 7,740 Caucasians).

Pitel, M., and Lerman, S. (1964). Amer. J. Ophthal., 58, 464 (Further studies on the effects of intrauterine vasoconstrictors on the fetal rat lens).

Ravenholt, R. T., and Levinski, M. J. (1965). Lancet, 1, 961 (Smoking during pregnancy).

Reinke, W. A., and Henderson, M. (1966). Arc\&. environm. Hlth, 12, 600 (Smoking and prematurity the presence of other variables).

Robson, J. M. (1963). Practitioner, 191, 136 (T) problem of teratogenicity). (Editorial.)

Rosenbaum, S. (1964). Harefuah, 66, 313 (The influence of smoking on the newborn). [Hebrew.]

Russell, C. S., Taylor, R., and Maddison, R. N. (1966). J. Obstet. Gynaec. Brit. Cwlth, 73, 742 (Some effects of smoking in pregnancy).

Savel, L. E., and Roth, E. (1962). Obstet. and Gynec., 20, 313 (Effects of smoking in pregnancy: a continuing retrospective study).

Simpson, W. J. (1957). Amer. J. Obstet. Gynec., 73, 808 (A preliminary report on cigarette smoking and the incidence of prematurity).

Steele, R., and Langworth, J. T. (1966). Canad. med. Ass. J., 94, 1165 (The relationship of antenatal and 3 postnatal factors to sudden unexpected death in infancy).

Tanaka, H. (1965). J. Jap. obstet. gynaec. Soc., 17, 1107 굴 (Studies on the etiological mechanism of fetal develop- 0 mental disorders caused by maternal smoking during pregnancy).

Underwood, P., Hester, L. L., Laffitte, T., Jr., and Gregg, 으․ K. V. (1965). Amer. J. Obstet. Gynec., 91, 270 (The $\mathrm{N}$ relationship of smoking to the outcome of pregnancy). $\mathrm{N}$ , Kesler, K. F., O'Lane, J. M., and Callagan, D. A. (1967). Obstet. and Gynec., 29, 1 (Parental smoking empirically related to pregnancy outcome).

Yerushalmy, J. (1964). Amer. J. Obstet. Gynec., 88, 505 б (Mother's cigarette smoking and survival of infant).

Young, I. M., and Pugh, L. G. (1963). J. Obstet. Gynaec. Brit. Cwlth, 70, 681 (The carbon monoxide content of $\overline{\mathscr{D}}$ foetal and maternal blood).

Zabriskie, J. R. (1963). Obstet. and Gynec., 21, $405^{\circ}$ (Effect of cigaret smoking during pregnancy: study of 2,000 cases). 